\title{
PENETAPAN AMBANG BATAS KADAR Fe TOTAL DALAM PUPUK ORGANIK YANG BERPOTENSI MENYEBABKAN KERACUNAN Fe TANAMAN PADI SAWAH
}

\author{
Cahyadi $^{1}$, Nia Yuliani ${ }^{2)^{*}}$ dan Srikandi ${ }^{2}$ \\ ${ }^{1}$ Balai Penelitian Lingkungan Pertanian \\ ${ }^{2)}$ Program Studi Biologi FMIPA Universitas Nusa Bangsa Bogor \\ Jl. KH Soleh Iskandar KM 4 Cimanggu Tanah Sareal, Bogor 16166 \\ *email : niayuliani88@yahoo.co.id
}

\begin{abstract}
Determination of Threshold Levels of Total Fe in Organic Fertilizer that Have Potential to Cause Fe Poisoning for Rice Plant
\end{abstract}

\begin{abstract}
The type and quality of organic fertilizers on the market either already registered or not registered are huge numbers. The Government has issued a Ministerial Regulation of Agriculture no 28 in 2009 on organic fertilizers, bio-fertilizers, and soil repair is now revised to Regulation of the Minister of Agriculture no 70 in 2011, in order to have a good quality of solid organic fertilizer that having Fe content does not exceed $9,000 \mathrm{mg} / \mathrm{kg}$. This study aims to establish the total Fe content in the organic fertilizer that could potentially lead then to $\mathrm{Fe}$ toxicity for rice plant. The results showed that the effect of organic fertilizer and Fe levels were not significantly different in plant height number,number of seedling, dry straw weight, $C$ Organic, cation exchange capacity $(C E C)$ and the grain content, but significantly different in plant height and number of tillers at 20 days after plantation. Fe - toxicity limited the total solid organic fertilizer with a dose of 1 ton / ha causing toxicity to rice varieties IR 64 on the ground Inceptisol of $54,318 \mathrm{mg} \mathrm{Fe} / \mathrm{kg}$. Threshold in Fe - organic fertilizer with a total dose of 1 ton / ha which could potentially lead to Fe deficiency IR 64 rice varieties at 12,682 $\mathrm{mg} \mathrm{Fel} \mathrm{kg}$, whereas Fe toxicity level was equal to $54,318 \mathrm{mg} \mathrm{Fe} / \mathrm{kg}$.
\end{abstract}

Keywords : TotalFe content, organicfertilizer, toxicity, rice

\begin{abstract}
ABSTRAK
Jenis dan mutu pupuk organik yang beredar di pasaran baik yang sudah terdaftar maupun yang belum terdaftar jumlahnya sangat banyak.Pemerintah telah mengeluarkan Peraturan Menteri Pertanian No. 28 Tahun 2009 tentang pupuk organik, pupuk hayati, dan pembenah tanah yang saat ini sudah direvisi menjadi Peraturan Menteri Pertanian No. 70 Tahun 2011 bahwa agar pupuk organik padat berkualitas baik maka kadar Fe yang ada tidak melebihi $9.000 \mathrm{mg} / \mathrm{kg}$. Penelitian ini bertujuan menetapkan kadar Fe total dalam pupuk organik yang berpotensi menyebabkan keracunan Fe untuk tanaman padi sawah. Hasil penelitian menunjukkan bahwa pengaruh pemberian pupuk organik dan kadar Fe tidak berbeda nyata pada tinggi tanaman, jumlah anakan, berat kering jerami, C-Organik, kapasitas tukar kation (KTK) dan isi gabah, tetapi berbeda nyata pada tinggi tanaman dan jumlah anakan pada 20 HST. Batas toksisitas Fe-total dalam pupuk organik padat dengan dosis 1 ton/ha yang berpotensi menyebabkan keracunan Fe untuk tanaman padi varietas IR 64 pada tanah inceptisol sebesar $54.318 \mathrm{mg} \mathrm{Fe} / \mathrm{kg}$. Ambang batas Fe-total dalam pupuk organik dengan dosis 1 ton/ha yang berpotensi menyebabkan kekurangan Fe untuk tanaman padi varietas IR 64 sebesar $12.682 \mathrm{mg} \mathrm{Fe} / \mathrm{kg}$, sedangkan tingkat keracunan Fe adalah sebesar $54.318 \mathrm{mg} \mathrm{Fe} / \mathrm{kg}$.
\end{abstract}

Kata kunci : Kadar Fe total, pupuk organik, toksisitas, padi

\section{PENDAHULUAN}

Penggunaan pupuk anorganik secara intensif pada padi sawahdapat menyebabkan penurunan kualitas tanah. Menurunnya kualitas tanah menye- babkan tanah menjadi rusak baik fisik, kimia, maupun biologi. Tanah yang rusak dicirikan oleh rendahnya daya sangga tanah dan efisiensi pemupukan, serta berkurangnya aktivitas mikroba perombak bahan organik tanah(Anonim, 
2005). Berbagai hasil penelitian mengindikasikan bahwa sebagian besar lahan pertanian intensif menurun produktivitasnya, karena lahan pertanian intensif telah mengalami degradasi, terutama terkait dengan sangat rendahnya kandungan C-organik dalam tanah. Sekitar $80 \%$ lahan sawah kering kandungan C-organik tanahnya kurang dari $1 \%$ (Aphani, 2001). Menurut Prasetyo dan Setyorini, (2008) hasil analisis 1.548 contoh tanah sawah dari beberapa provinsi di Indonesia, sekitar $66 \%$ mempunyai kandungan $\mathrm{C}$-organik rendah $<2 \%$ dan sekitar $34 \%$ yang mempunyai kandungan C-organik $>2 \%$.

Pada tanah dengan kandungan $\mathrm{C}$ organik rendah menyebabkan kebutuhan pemupukan makin meningkat dengan efisiensi yang merosot akibat tingginya tingkat pencucian.Penggunaan pupuk organik dalam jangka panjang dapat meningkatkan produktivitas lahan dan dapat mencegah degradasi lahan.Pupuk organik yang beredar di pasaran baik yang sudah terdaftar maupun yang belum terdaftar jenis dan jumlahnya sangat banyak, sehingga diperlukan persyaratan atau kriteria yang mengatur mutu dan kualitas pupuk organik. Untuk itu, pemerintah mengeluarkan Permentan No. 70 Tahun 2011 tentang pupuk organik, pupuk hayati, dan pembenah tanah, yang mana kadar $\mathrm{Fe}$ merupakan salah satu persyaratan teknis yang harus dipenuhi dalam pupuk organik. Agar pupuk organik berkualitas baik maka kadar $\mathrm{Fe}$ yang ada dalam pupuk organik padat tidak melebihi $9000 \mathrm{mg} / \mathrm{kg}$. Namun, pada kenyataannya masih banyak kadar $\mathrm{Fe}$ total dalam pupuk organik yang beredar di pasaran saat ini mencapai $20.000 \mathrm{mg} / \mathrm{kg}$ bahkan sampai $50.000 \mathrm{mg} / \mathrm{kg}$, sekalipun pupuk organik tersebut sebagian besar bahan bakunya berasal dari kotoran sapi.

Tujuan penelitian adalah untuk penetapan kadar Fe total dalam pupuk organik yang berpotensi menyebabkan keracunan untuk tanaman padi sawah.

\section{BAHAN DAN METODA}

Bahan yang digunakan adalah tanah sawah yang diambil dari Sukamandi (tanah Inseptisol) dari kedalaman 0-20 $\mathrm{cm}$, plastik, karung, pot/ember, penggaris, benih padi varietas IR 64, karena varietas padi ini tergolong toleran terhadap kandungan besi (Suhartini, 2004), pupuk dasar (urea, SP-36, dan $\mathrm{KCl}$ ), pupuk organik padat yang beredar di pasaran, dan pupuk organik yang bersumber dari kotoran hewan, kertas label, air bebas ion untuk penggenangan, pipa, lem perekat, ember kecil untuk penampung air dan bahan-bahan kimia untuk percobaan di laboratorium. Alat yang digunakan dalam penelitian ini adalah: timbangan, ayakan, Atomic Absorption Spektrofotometer (AAS), $\mathrm{pH}$ meter, timbangan analitik dan lain-lain.

Penelitian yang dilakukan menggunakan Rancangan Acak Lengkap (RAL) dan diulang 3 kali dengan perlakuan $\mathrm{F}_{0}=$ Kontrol (tanpa penambahan pupuk organik padat), $\mathrm{F}_{1}=$ Pupuk organik padat, $F_{2}=$ Pupuk organik padat $+8.000 \mathrm{mg} / \mathrm{kg} \mathrm{Fe} \mathrm{Cl}_{3}$, $\mathrm{F}_{3}=$ Pupuk organik padat $+16.000 \mathrm{mg} /$ $\mathrm{kg} \mathrm{Fe} \mathrm{Cl}_{3}, \mathrm{~F}_{4}=$ Pupuk organik padat + $24.000 \mathrm{mg} / \mathrm{kg} \mathrm{Fe} \mathrm{Cl}_{3}, \mathrm{~F}_{5}=$ Pupuk organik padat $+32.000 \mathrm{mg} / \mathrm{kg} \mathrm{Fe} \mathrm{Cl}_{3}$, $\mathrm{F}_{6}=$ pupuk organik padat $+64.000 \mathrm{mg} /$ $\mathrm{kg} \mathrm{Fe} \mathrm{Cl}_{3}$. Hasil uji $\mathrm{F}$ yang menunjukan pengaruh nyata, dilakukan uji lanjut dengan menggunakan Uji Jarak Berganda Duncan (DMRT) (Hanafiah, 1995).

\section{Cara Kerja}

\section{Pengambilan contoh tanah}

Contoh tanah diambil secara komposit dari lokasi lahan sawah di Sukamandi berdasarkan jenis mineral liat yaitu 1:1 dan 2:1 dengan jenis tanah Inseptisol/Aluvial. Contoh tanah komposit merupakan gabungan dari 5-10 sub contoh yang diambil secara acak pada kedalaman $\quad 0-20 \mathrm{~cm}$ masing-masing sebanyak 200-250 kg. Semua contoh dimasukkan ke dalam ember plastik, 
diaduk hingga homogen, diambil sekitar $1 \mathrm{~kg}$ dan dimasukkan ke dalam kantong plastik yang telah diberi label.

\section{Aplikasi pupuk organik berkadar Fe total tinggi}

Contoh tanah dikeringanginkan, kemudian ditumbuk dan diayak dengan ayakan berukuran $4 \mathrm{~mm}$, lalu ditimbang setara dengan $10 \mathrm{~kg}$ per pot berat kering mutlak (BKM). Pupuk organik padat yang digunakan 1 jenis yaitu yang berasal dari kotoran sapi selanjutnya kadar Fe yang ada dalam pupuk organik tersebut diperkaya dengan $\mathrm{Fe}$ yang berasal dari $\mathrm{FeCl}_{3}$, masing-masing sesuai dengan takaran dalam perlakuan, lalu dicampur. Kemudian pupuk organik tersebut diaplikasikan ke dalam pot-pot yang sudah disiapkan dengan dosis 1 ton/ha $(0,5 \mathrm{~g} / \mathrm{kg}$ tanah $)$. Tanah lalu digenangi air (ketinggian air dipertahankan sekitar $3 \mathrm{~cm}$ ), lalu diinkubasi selama 7 hari.Setelah inkubasi, saat tanam tanah diberi pupuk dasar dengan dosis $150 \mathrm{mg} / \mathrm{kg} \quad \mathrm{N}, 100 \mathrm{mg} / \mathrm{kg} \quad \mathrm{P}_{2} \mathrm{O}_{5}$, dan $75 \mathrm{mg} / \mathrm{kg} \quad \mathrm{K}_{2} \mathrm{O}$ masing-masing berasal dari urea, SP-36, dan $\mathrm{KCl}$.

Benih padi varietas IR 64 disemai terlebih dahulu, setelah 21 HSS (hari setelah semai) bibit padi dipindah ke dalam pot percobaan dan ditanam sebanyak 2 bibit/pot. Pengamatan dilakukan terhadap peubah pertumbuhan tanaman, yaitu: Tinggi tanaman dan jumlah anakan setiap 10 hari sekali sampai menjelang panen, saat panen diamati sistem perakarannya (panjang, berat basah dan kering akar), parameter lain yang diamati adalah: jumlah anakan produktif, berat gabah basah, berat gabah kering isi, berat kering jerami, berat 1000 butir, dan parameter yang diukur, adalah: (1) Analisis tanah sebelum percobaan (2) Analisis hara pupuk organik, (3) Analisis tanah setelah panen.

\section{Penetapan Kadar Fe total dalam pupuk organik padat}

Penetapan kadar Fe-total dalam pupuk organik padat untuk padi sawah ditetapkan dengan menggunakan metode kurva kuadratik yang menghubungkan hasil relatif padi (sumbu Y) dengan kadar Fe yang ada dalam pupuk organik (sumbu X) Apabila kurva hubungan hasil relatif padi dan kadar Fe mengikuti persamaan $\mathrm{Y}=\mathrm{a} \mathrm{X}^{2}+\mathrm{bX}+\mathrm{c}$, dimana $\mathrm{Y}=$ hasil relatif padi (\%), $\mathrm{X}=$ kadar Fe yang ada dalam pupuk organik (ppm), dan $\mathrm{a}, \mathrm{b}$, dan $\mathrm{c}=$ konstanta, maka batas keracunan $\mathrm{Fe}$ untuk padi adalah $\mathrm{X}$ di atas produksi maksimum pada saat $\mathrm{Y}=$ $90 \%$. Nilai $Y=90 \%$ ditetapkan berdasarkan asumsi bahwa penurunan hasil sebanyak $10 \%$ pada kadar $\mathrm{Fe}$ di atas produksi maksimum sudah mengindikasikan adanya gejala keracunan $\mathrm{Fe}$ pada tanaman padi(Pendias dan Pendias, 1995 dalam Alloway, 1995).

\section{HASIL DAN PEMBAHASAN}

\section{Karakteristik Tanah}

Jenis tanah Inseptisol yang digunakan bertekstur halus, dengan kandungan fraksi liat $>50 \%$ Kadar Corganik tanah sebesar 2,12\% tergolong sedang dan reaksi tanah ( $\mathrm{pH}$ aktual) tergolong masam sebesar 4,86 - 5,19. Kadar $\mathrm{N}$ total tanah sebesar $0,21 \%$ tergolong sedang, kejenuhan basa sebesar $>100$ tergolong sangat

tinggi, kadar $\mathrm{P}$ dan $\mathrm{K}$ total masingmasing sebesar 79,30 dan $99,00 \mathrm{mg} / \mathrm{kg}$ tergolong sangat tinggi, P-tersedia (Bray I) sebesar $11,52 \mathrm{mg} / \mathrm{kg}$ tergolong tinggi. Nilai kapasitas tukar kation (KTK) tanah sebesar $16,95 \mathrm{cmol}(+) / \mathrm{kg}$ tergolong sedang. Kadar Fe-total pada tanah sebesar $32.157 \mathrm{mg} / \mathrm{kg}$, sedangkan kadar Fe tersedia sebesar $39,72 \mathrm{mg} / \mathrm{kg}$ tergolong sedang.

\section{Karakteristik Pupuk Organik Padat}

Karakteristik pupuk organik padat yaitu untuk parameter $\mathrm{pH}, \mathrm{C}$ organik, $\mathrm{N}$ total, $\mathrm{P}_{2} \mathrm{O}_{5}, \mathrm{~K}_{2} \mathrm{O}$ dan kadar $\mathrm{Fe}$-total berturut-turut yaitu 6,$77 ; 14,77 \% ; 0,44$ $\% ; 1,0 \% ; 6,43 \%$; dan $2614 \mathrm{mg} / \mathrm{kg}$.

Kandungan kadar air dan rasio $\mathrm{C} / \mathrm{N}$ belum sesuai dengan kriteria yang 
dipersyaratkan karena kadar air pupuk organik padat tersebut melebihi $15 \%$ dan rasio $\mathrm{C} / \mathrm{N}$ melebihi $25 \%$. Tingginya kadar air dalam contoh pupuk organik padat disebabkan karena belum sempurnanya proses pengeringan sehingga pada saat contoh pupuk organik padat diambil kadar airnya masih tinggi..Kadar $\mathrm{Pb}$ dan $\mathrm{Cd}$ masingmasing sebesar 25,48 dan $7,82 \mathrm{mg} / \mathrm{kg}$. Nilai tersebut memenuhi persyaratan menurut Permentan No. 28 Tahun 2009 dimana membatasi kadar $\mathrm{Pb}$ dan $\mathrm{Cd}$ masing-masing kurang dari 50 dan 10 $\mathrm{mg} / \mathrm{kg}$.

\section{Karakteristik Tanah dan Tanaman Setelah Panen}

Kandungan C-organik, KTK dan $\mathrm{pH}$ pada tanah setelah panen disajikan pada Tabel 1 bahwa perlakuan tidak menunjukkan pengaruh yang nyata terhadap kadar C-organik maupun KTK. Hal ini menunjukan bahwa penambahan pupuk organik dan kadar $\mathrm{Fe}$ tidak memberikan pengaruh yang nyata. Sedangkan $\mathrm{pH}$ tanah setelah panen ada pada kisaran netral.Nilai KTK pada kontrol tidak berbeda nyata dengan perlakuan penambahan kadar Fe.

Kandungan $\mathrm{Fe}$ pada tanaman dan tanah disajikan pada Tabel 2, kandungan Fe pada tanaman padi menunjukkan perbedaan yang nyata, akan tetapi kandungannya masih di bawah 300 $\mathrm{mg} / \mathrm{kg}$.Hasil analisis kadar Fe-total pada tanah, perlakuan penambahan $\mathrm{Fe} 64000$ $\mathrm{mg} / \mathrm{kg}$ (F6) menunjukkan perbedaan yang nyata dengan perlakuan lainnya (Tabel 2). Perlakuan F6 mengandung kadar Fe sebesar 2942,44 mg/kg, sehingga pertumbuhan tanaman menjadi tidak normal (kerdil dan jumlah anakan sedikit).Penurunan $\mathrm{Fe}$ total dalam tanah diakibatkan lamanya inkubasi, penambahan air, oksidasi, pencucian dan penguapan baik pada kontrol maupun pada perlakuan penambahan kadar Fe.

Tabel 1. Rataan C-Organik(\%), KTK $\left(\mathrm{cmol}^{+} / \mathrm{kg}\right)$ dan $\mathrm{pH}$ pada Tanah Setelah Panen.

\begin{tabular}{cccc}
\hline Perlakuan & C-Organik & KTK & pH \\
\hline F0 & $0,99 \mathrm{a}$ & $17,68 \mathrm{a}$ & 6.81 \\
F1 & $1,30 \mathrm{a}$ & $18,20 \mathrm{a}$ & 6.67 \\
F2 & $1,20 \mathrm{a}$ & $18,42 \mathrm{a}$ & 6.33 \\
F3 & $1,24 \mathrm{a}$ & $15,30 \mathrm{a}$ & 6.60 \\
F4 & $1,13 \mathrm{a}$ & $16,55 \mathrm{a}$ & 6.30 \\
F5 & $1,07 \mathrm{a}$ & $15,43 \mathrm{a}$ & 6.53 \\
F6 & $1,39 \mathrm{a}$ & $21,89 \mathrm{a}$ & 6.66 \\
\hline
\end{tabular}

Angka-angka pada kolom yang sama yang diikuti oleh huruf yang sama tidak berbeda nyata pada taraf 5\% Uji Jarak Berganda Duncan (DMRT)

Tabel 2. Rataan Fe Total(mg/kg) pada Tanah Sebelum dan Setelah Panen dan Tanaman

\begin{tabular}{cccl} 
50HST & \multicolumn{3}{c}{} \\
\hline $\begin{array}{c}\text { Tanah sebelum } \\
\text { panen }\end{array}$ & Perlakuan & $\begin{array}{c}\text { Tanah setelah } \\
\text { panen }\end{array}$ & $\begin{array}{c}\text { Tanaman } \\
50 \mathrm{HST}\end{array}$ \\
\hline $32.157,00$ & F0 & $726,09 \mathrm{f}$ & $298,20 \mathrm{a}$ \\
34.771 .00 & F1 & $914,94 \mathrm{c}$ & $175,32 \mathrm{~cd}$ \\
$42.771,00$ & F2 & $857,50 \mathrm{e}$ & $152,36 \mathrm{~d}$ \\
$58.771,00$ & F3 & $872,37 \mathrm{de}$ & $197,76 \mathrm{bcd}$ \\
$82.771,00$ & F4 & $898,21 \mathrm{~cd}$ & $241,13 \mathrm{~b}$ \\
$114.771,00$ & F5 & $947,63 \mathrm{~b}$ & $148,54 \mathrm{~d}$ \\
$178.771,00$ & F6 & $2942,44 \mathrm{a}$ & $204,49 \mathrm{bc}$ \\
\hline
\end{tabular}

Angka-angka pada kolom yang sama yang diikuti oleh huruf yang sama tidak berbeda nyata pada taraf 5\% Uji Jarak Berganda Duncan (DMRT) 
Tabel 3. Rataan Tinggi Tanaman (cm) Padi IR 64

\begin{tabular}{|c|c|c|c|c|c|}
\hline \multirow{2}{*}{ Perlakuan } & \multicolumn{5}{|c|}{ Hari Setelah Tanam (HST) } \\
\hline & 10 & 20 & 50 & 70 & 100 \\
\hline F0 & $21,50 \mathrm{a}$ & $44,17 \mathrm{~b}$ & $72,33 \mathrm{a}$ & $83,67 a$ & $88,17 \mathrm{a}$ \\
\hline $\mathrm{F} 1$ & $23,67 \mathrm{a}$ & $49,83 \mathrm{a}$ & $73,67 \mathrm{a}$ & $89,17 \mathrm{a}$ & $92,50 \mathrm{a}$ \\
\hline $\mathrm{F} 2$ & $24,83 \mathrm{a}$ & $49,00 \mathrm{a}$ & $73,33 \mathrm{a}$ & $86,33 \mathrm{a}$ & $90,67 \mathrm{a}$ \\
\hline F3 & $24,17 \mathrm{a}$ & $51,83 \mathrm{a}$ & $72,67 \mathrm{a}$ & $82,50 \mathrm{a}$ & $88,17 \mathrm{a}$ \\
\hline F4 & $23,00 \mathrm{a}$ & $49,83 \mathrm{a}$ & $76,00 \mathrm{a}$ & $86,33 \mathrm{a}$ & $95,00 \mathrm{a}$ \\
\hline F5 & $22,17 \mathrm{a}$ & $51,83 \mathrm{a}$ & $72,67 \mathrm{a}$ & $87,33 \mathrm{a}$ & $91,33 \mathrm{a}$ \\
\hline F6 & $22,50 \mathrm{a}$ & $51,17 \mathrm{a}$ & $72,00 \mathrm{a}$ & $85,00 \mathrm{a}$ & $88,00 \mathrm{a}$ \\
\hline \multirow{2}{*}{ Perlakuan } & \multicolumn{5}{|c|}{ Hari Setelah Tanam (HST) } \\
\hline & 10 & 20 & 50 & 70 & 100 \\
\hline F0 & $21,50 \mathrm{a}$ & $44,17 \mathrm{~b}$ & $72,33 \mathrm{a}$ & $83,67 \mathrm{a}$ & $88,17 \mathrm{a}$ \\
\hline $\mathrm{F} 1$ & $23,67 \mathrm{a}$ & $49,83 \mathrm{a}$ & $73,67 \mathrm{a}$ & $89,17 \mathrm{a}$ & $92,50 \mathrm{a}$ \\
\hline $\mathrm{F} 2$ & $24,83 \mathrm{a}$ & $49,00 \mathrm{a}$ & $73,33 \mathrm{a}$ & $86,33 \mathrm{a}$ & $90,67 \mathrm{a}$ \\
\hline F3 & $24,17 \mathrm{a}$ & $51,83 \mathrm{a}$ & $72,67 \mathrm{a}$ & $82,50 \mathrm{a}$ & $88,17 \mathrm{a}$ \\
\hline F4 & $23,00 \mathrm{a}$ & $49,83 \mathrm{a}$ & $76,00 \mathrm{a}$ & $86,33 \mathrm{a}$ & $95,00 \mathrm{a}$ \\
\hline F5 & $22,17 \mathrm{a}$ & $51,83 \mathrm{a}$ & $72,67 \mathrm{a}$ & $87,33 \mathrm{a}$ & $91,33 a$ \\
\hline F6 & $22,50 \mathrm{a}$ & $51,17 \mathrm{a}$ & $72,00 \mathrm{a}$ & $85,00 \mathrm{a}$ & $88,00 \mathrm{a}$ \\
\hline
\end{tabular}

Angka-angka pada kolom yang sama yang diikuti oleh huruf yang sama tidak berbeda nyata pada taraf $5 \%$ Uji Jarak Berganda Duncan (DMRT).

\section{Pertumbuhan Tanaman}

\section{Tinggi Tanaman}

Pertumbuhan tanaman padi varietas IR 64 meliputi tinggi tanaman dan jumlah anakan diamati sampai menjelang panen. Hasil pengamatan tinggi tanaman padi pada umur $10,20,50,70$ dan 100 hari setelah tanam (HST) disajikan pada Tabel 3. Tinggi tanaman pada umur 10 HST menunjukan bahwa perlakuan tidak berpengaruh nyata terhadap tinggi tanaman, hal ini diduga karena sampai tanaman umur 10 HST tambahan bahan organik belum diserap oleh tanaman.

Pada pengamatan 20 HST tinggi tanaman terutama pada perlakuan kontrol (F0) berbeda nyata dengan perlakuan yang menggunakan pupuk organik dan penambahan $\mathrm{Fe}$. Pada pengamatan 50, 70 dan 100 HST perlakuan tidak berpengaruh nyata terhadap tinggi tanaman (Tabel 3). Tanaman padi dari 70 sampai dengan 100 HST pada berbagai jenis perlakuan dengan kadar $\mathrm{FeCl}_{3}$ yang ditambahkan dalam pupuk organik padat menunjukkan pertumbuhan yang baik.

\section{Jumlah Anakan}

Hasil pengamatan jumlah anakan pada umur 10, 20, 50,70 dan 100 HST disajikan pada Tabel5. Pada pengamatan 10 HST jumlah anakan belum ada penambahan. Pada pengamatan $20 \mathrm{HST}$, F0/kontrol berbeda nyata F1 dan F6, hal ini adanya penambahan $\mathrm{Fe}$ sudah mempengaruhi jumlah anakan. Sedang-kan jumlah anakan terus meningkat sampai dengan padi umur 70 HST dan cenderung tetap stabil sampai padi menjelang panen. Ini menunjukkan bahwa pada umur padi 70 HST merupa-kan pertumbuhan maksimum .karena pada fase ini tanaman padi tergolong pada ase vegetatif cepat. Setelah umur 70 sampai dengan $100 \mathrm{HST}$, tanaman padi mengalami fase vegetatif lambat yang ditandai dengan beberapa anakan yang mati. 


\section{Hasil Panen Tanaman Padi}

\section{Bobot Kering Padi}

Bobot basah dan kering jerami, basah dan kering akar, serta panjang akar disajikan pada Tabel5, bobot basah jerami pada perlakuan F0 dan F4 menunjukkan perbedaan yang nyata dengan perlakuan F6, sedangkan bobot kering jerami tidak berbeda nyata antar perlakuan.Penambahan kadar $\mathrm{Fe}$ semakin tinggi mengakibatkan bobot jerami semakin rendah. Bobot basah dan kering akar pada F0, F1 dan F4 menunjukkan perbedaan yang nyata dengan perlakuan lainnya, semakin besar penambahan $\mathrm{Fe}$ akan mempengaruhi terhadap pertumbuhan akar dan panjang akar Menurut Todano dan Yoshida (1978) kadar besi yang berlebihan dapat membentuk lapisan oksida ferri pada permukaan akar, sehingga menghambat penyerapan hara, menurunkan daya oksidasi akar, dan daya pencegahan Fe oleh akar.

\section{Hasil Padi}

Hasil padi yang diamati setelah panen meliputi gabah isi/rumpun, berat 1000 butir dan jumlah malai/rumpun dan disajikan pada Tabel 6,pengamatan gabah isi tidak menunjukkan perbedaam yang nyata antar perlakuan, sedangkan pada pengamatan berat 1000 butir menunjukkan perbedaan yang nyata antar perlakuan. Perlakuan F4 menghasilkan bobot 1000 butir tertinggi dibandingkan dengan perlakuan lainnya. Penambahan $\mathrm{Fe}$ pada pupuk organik sampai dengan $24000 \mathrm{mg} / \mathrm{kg}$, bobot 1000 butir meningkat kemudian menurun pada penambahan $\mathrm{Fe} 32.000$ $64.000 \mathrm{mg} / \mathrm{kg}$. Hal ini menunjukkan bahwa untuk memperoleh bobot 1000 butir yang optimal kandungan Fe pada pupuk organik berkisar antara 24.000 dan $32.000 \mathrm{mg} / \mathrm{kg}$. Hasil analisis statistik pada jumlah malai/rumpun perlakuan F2 dan F4 menunjukkan perbedaan yang nyata dengan perlakuan lainnya.

\section{Kadar Fe-Total dalam Pupuk Organik Padat}

Kadar Fe - total dalam pupuk organik padat yang diaplikasikan sebanyak 1 ton/ha yang berpotensi menyebabkan keracunan pada tanaman padi sawah IR 64 pada tanah inseptisol adalah $\mathrm{Y}=-2 \mathrm{E}-08 \mathrm{X}^{2}+0,001 \mathrm{X}+80,535$ koefesien regresi $\mathrm{R}^{2}=0,701$ yang artinya bahwa sebanyak $70 \%$ hasil padi dipengaruhi oleh kadar Fe-total dalam pupuk organik padat dan sisanya $30 \%$ dipengaruhi oleh faktor lain dan banyak percobaann $=21$. Nilai kadar Fe-total yang diperoleh sebesar $54.318 \mathrm{mg} / \mathrm{kg}$, tingginya nilai kadar Fe-total pada tanah inseptisolkarena berkaitan dengan tingginya daya sangga tanah tersebut terhadap unsur Fe. Hal ini menunjukkan bahwa kadar Fe-total sebesar 54.318 $\mathrm{mg} / \mathrm{kg}$ dalam pupuk organik padat yang diberikan sebanyak 1 ton/ha pada tanah untuk tanaman padi varietas IR 64 meskipun tidak menunjukkan gejala bronzing pada daun tanaman padi namun sudah menurunkan hasil panen padi sebesar $10 \%$ dari hasil maksimum. Nilai $Y=90 \%$ ditetapkan berdasarkan asumsi bahwa penurunan hasil sebanyak $10 \%$ pada kadar $\mathrm{Fe}$ di atas produksi maksimum sudah mengindikasikan adanya gejala keracunan $\mathrm{Fe}$ pada tanaman padi(Pendias dan Pendias, 1995 dalam Alloway, 1995).

Kadar Fe-total dalam pupuk organik padat yang berada pada kisaran 12.682 sampai $54.318 \mathrm{mg} / \mathrm{kg}$, berada pada kisaran level kecukupan. Artinya jika kadar $\mathrm{Fe}$ dalam pupuk organik kurang dari $12.682 \mathrm{mg} / \mathrm{kg}$ makatanaman padi akan mengalami kekurangan $\mathrm{Fe}$ dan apabila melebihi $54.318 \mathrm{mg} / \mathrm{kg}$ tanaman padi akan mengakibatkan keracunan. Sehingga dari gambar kuadratik dapat ditetapkan bahwa kadar Fe-total dalam pupuk organik padat yang diaplikasikan sebanyak 1 ton/ha yang berpotensi menyebabkan keracunan $\mathrm{Fe}$ pada tanaman padi varietas IR 64 adalah sebesar $54.318 \mathrm{mg} / \mathrm{kg}$. 


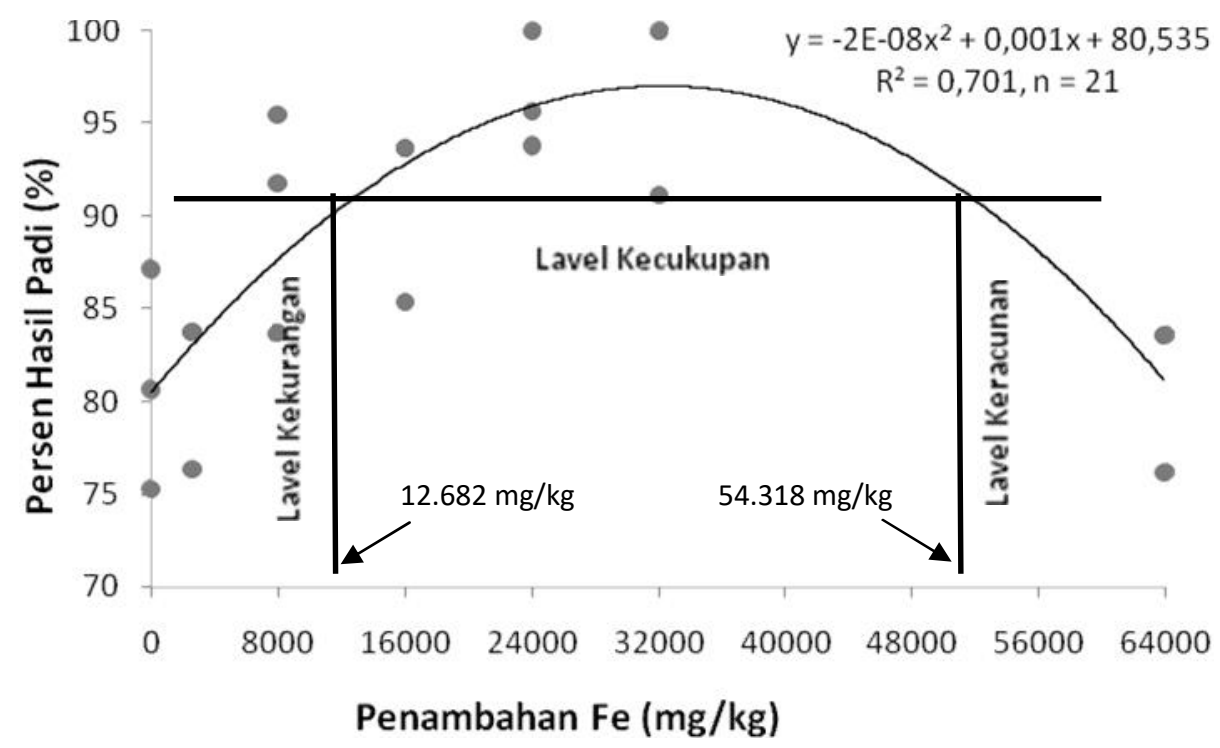

Gambar1. Kurva Kuadratik dalam Penetapan Kadar Fe-Total dalam Pupuk Organik untuk Padi Varietas IR 64.

Tabel 4. Rataan Jumlah Anakan Tanaman Padi IR 64

\begin{tabular}{cccccc}
\hline \multirow{2}{*}{ Perlakuan } & \multicolumn{5}{c}{ Jumlah Anakan Hari Setelah Tanam (HST) } \\
\cline { 2 - 6 } & 10 & 20 & 50 & 70 & 100 \\
\hline F0 & 1,00 & $2,00 \mathrm{~b}$ & $12,33 \mathrm{a}$ & $20,67 \mathrm{a}$ & $23,33 \mathrm{a}$ \\
F1 & 1,00 & $3.00 \mathrm{a}$ & $15,33 \mathrm{a}$ & $22,67 \mathrm{a}$ & $28,00 \mathrm{a}$ \\
F2 & 1,00 & $2,33 \mathrm{ba}$ & $16,67 \mathrm{a}$ & $25,67 \mathrm{a}$ & $27,00 \mathrm{a}$ \\
F3 & 1,00 & $2,33 \mathrm{ba}$ & $15,67 \mathrm{a}$ & $19,67 \mathrm{a}$ & $23,67 \mathrm{a}$ \\
F4 & 1,00 & $2,33 \mathrm{ba}$ & $16,67 \mathrm{a}$ & $26,67 \mathrm{a}$ & $27,33 \mathrm{a}$ \\
F5 & 1,00 & $2,67 \mathrm{ba}$ & $17,67 \mathrm{a}$ & $21,00 \mathrm{a}$ & $26,00 \mathrm{a}$ \\
F6 & 1,00 & $3,00 \mathrm{a}$ & $16,67 \mathrm{a}$ & $22,33 \mathrm{a}$ & $25,33 \mathrm{a}$ \\
\hline
\end{tabular}

Angka-angka pada kolom yang sama yang diikuti oleh huruf yang sama tidak berbeda nyata pada taraf $5 \%$ Uji Jarak Berganda Duncan (DMRT).

Tabel 5. Rataan Berat Basah Jerami dan Akar, Berat Kering Jerami dan Akar, serta Panjang Akar Tanaman Padi IR 64.

\begin{tabular}{clcccc}
\hline \multirow{2}{*}{ Perlakuan } & \multicolumn{5}{c}{ Berat (gr) } \\
\cline { 2 - 5 } & $\begin{array}{c}\text { Basah } \\
\text { Jerami }\end{array}$ & $\begin{array}{c}\text { Kering } \\
\text { Jerami }\end{array}$ & $\begin{array}{c}\text { Basah } \\
\text { Akar }\end{array}$ & $\begin{array}{c}\text { Kering } \\
\text { Akar }\end{array}$ & Akar \\
\hline F0 & $91,53 \mathrm{a}$ & $28,93 \mathrm{a}$ & $24,89 \mathrm{a}$ & $13,50 \mathrm{a}$ & $31,33 \mathrm{~b}$ \\
F1 & $85,24 \mathrm{a}$ & $32,76 \mathrm{a}$ & $3,39 \mathrm{c}$ & $3,21 \mathrm{~b}$ & $32,33 \mathrm{~b}$ \\
F2 & $80,03 \mathrm{ab}$ & $32,84 \mathrm{a}$ & $4,14 \mathrm{c}$ & $3,45 \mathrm{~b}$ & $41,00 \mathrm{a}$ \\
F3 & $79,28 \mathrm{ab}$ & $28,56 \mathrm{a}$ & $11,88 \mathrm{bc}$ & $5,99 \mathrm{~b}$ & $35,00 \mathrm{~b}$ \\
F4 & $86,25 \mathrm{a}$ & $28,43 \mathrm{a}$ & $17,73 \mathrm{ab}$ & $11,95 \mathrm{a}$ & $34,00 \mathrm{~b}$ \\
F5 & $78,60 \mathrm{ab}$ & $27,25 \mathrm{a}$ & $4,05 \mathrm{c}$ & $3,38 \mathrm{~b}$ & $34,67 \mathrm{~b}$ \\
F6 & $61,55 \mathrm{~b}$ & $33,21 \mathrm{a}$ & $5,07 \mathrm{c}$ & $4,64 \mathrm{~b}$ & $36,33 \mathrm{~b}$ \\
\hline
\end{tabular}

Angka-angka pada kolom yang sama yang diikuti oleh huruf yang sama tidak berbeda nyata pada taraf $5 \%$ Uji Jarak Berganda Duncan (DMRT). 
Tabel 6.Rataan Berat Gabah Isi, Berat 1000 Butir dan Jumlah Malai/Rumpun pada Tanaman Padi.

\begin{tabular}{cccc}
\hline \multirow{2}{*}{ Perlakuan } & \multicolumn{2}{c}{ Berat (gr) } & \multirow{2}{\text{Jumlah}}{} \\
\cline { 2 - 3 } & Gabah Isi & $1000 \mathrm{butir}$ & malai/rumpun \\
\hline F0 & $52,58 \mathrm{a}$ & $25,31 \mathrm{bc}$ & $20,50 \mathrm{~d}$ \\
F1 & $50,57 \mathrm{a}$ & $25,11 \mathrm{bc}$ & $23,50 \mathrm{~cd}$ \\
F2 & $56,20 \mathrm{a}$ & $25,44 \mathrm{bc}$ & $30,50 \mathrm{a}$ \\
F3 & $56,56 \mathrm{a}$ & $24,94 \mathrm{c}$ & $23,00 \mathrm{~cd}$ \\
F4 & $60,23 \mathrm{a}$ & $26,23 \mathrm{a}$ & $29,00 \mathrm{ab}$ \\
F5 & $60,44 \mathrm{a}$ & $25,54 \mathrm{~b}$ & $25,50 \mathrm{bc}$ \\
F6 & $50,47 \mathrm{a}$ & $25,15 \mathrm{bc}$ & $22,00 \mathrm{~cd}$ \\
\hline
\end{tabular}

Angka-angka pada kolom yang sama yang diikuti oleh huruf yang sama tidak berbeda nyata pada taraf 5\% Uji Jarak Berganda Duncan (DMRT).

\section{KESIMPULAN}

Pemberian pupuk organik dan kadar Fe tidak berbeda nyata pada tinggi tanaman, jumlah anakan, berat kering jerami, C - Organik, kapasitas tukar kation (KTK) dan gabah isi, kecuali pada 20 HST berbeda nyata pada tinggi tanaman dan jumlah anakan. Perlakuan penambahan $\mathrm{Fe}$ berbeda nyata pada $\mathrm{Fe}$ totaltanaman dan tanah, berat basah jerami, berat basah dan kering akar, panjang akar, berat 1000 butir dan jumlah malai/rumpun. Batas toksisitas Fe-total dalam pupuk organik dengan dosis 1 ton/ha yang berpotensi menyebabkan keracunan Fe untuk tanaman padi varietas IR 64 pada tanah inceptisol sebesar $54.318 \mathrm{mg} / \mathrm{kg}$. Kadar Fe-total dalam pupuk organik dengan dosis 1 ton/ha yang berpotensi menyebabkan kekurangan $\mathrm{Fe}$ untuk tanaman padi varietas IR 64 sebesar $12.682 \mathrm{mg} / \mathrm{kg}$.

\section{DAFTAR PUSTAKA}

Anonim. 2005. Pupuk Organik Tingkatkan Produksi Pertanian. Warta Penelitian dan Pengembangan Pertanian 27 (6). Balai Penelitian Tanah. Bogor.

Alloway, B. J. 1995. Heavy Metals in Soils. 2rd Edition. Blackie Academic \& Professional Chapman \& Hall. London-
Glasgow-Wenheim-New

York. Tokyo-MelbourneMadras.368.

Aphani. 2001.Kembali ke Pupuk Organik. Kanwil Deptan Sumsel.Sinartani. No. 2880.

Hanafiah, K. A. 1995. Rancangan Percobaan: Teori dan Aplikasi. Edisi 2, Cetakan 4. PT Raja Grafindo Persada. Jakarta. 238p.

Todano, T. and S. Yoshida. 1978. Chemical changes in submerged soils and their effect on rice growth. In International Rice Research Intitute. Soil and Rice. Los Banos, Laguna, Philippines. p. 399-419.

Peraturan Menteri Pertanian No.28/ Permentan/ SR.130/ 5/ 2009 Tentang Pupuk Organik, Pupuk Hayati, dan Pembenah Tanah.

Peraturan Menteri Pertanian No.70/ Permentan/ SR.140/ 10/ 2011 Tentang PupukOrganik, Pupuk Hayati, dan Pembenah Tanah.

Prasetyo, B.H dan D. Setyorini. 2008. Karakteristik tanah sawah dari endapan aluvial dan pengelolaannya. Jurnal Sumberdaya 
Lahan 2 (1). Balai Besar Litbang Sumber Daya Lahan Pertanian. Badan Litbang Pertanian. 1-14p.

Suhartini,T. 2004. Perbaikan varietas padi untuk lahan keracunan besi. Balai Besar Penelitian dan Pengembangan Bioteknologi dan Sumberdaya Genetik Pertanian. Bogor: Buletin Plasma Nutfah 10 (1).
Suhartini,T. 2004. Perbaikan varietas padi untuk lahan keracunan besi. Balai Besar Penelitian dan Pengembangan Bioteknologi dan Sumberdaya Genetik Pertanian. Bogor: Buletin Plasma Nutfah 10 (1).

Yoshida, S. 1981. Fundamentals of rice crops science. International Rice Research Institut, Los Banos, Laguna, Philippines. 